\title{
IDEATIONAL AND INTERPERSONAL MEANINGS OF CHILDREN NARRATIVES IN INDONESIAN PICTUREBOOKS
}

\author{
Budi Hermawan \\ Didi Sukyadi \\ Universitas Pendidikan Indonesia \\ budihermawan@upi.edu; dsukyadi@upi.edu
}

First received: 10 January 2016

Final proof received: 28 September 2017

\begin{abstract}
Recent understanding as strongly believed by studies investigating the interactive or interpersonal meanings of images in such printed texts as textbooks and picturebooks shows that interpersonal relation can be established not only through verbal sentences as the primarily representational mode of our experiences but can also be represented through visual forms such as photographs and pictures. Further, studies on how meanings are represented through verbal and visual modes have revealed how readers' experiences and readers' social roles in relation to the content of the texts are constructed. The construction of readers' social roles through the use of images in printed texts has been regarded to be parallel with how interactants' social position is enacted in direct communication relying on the use of verbal sentences. In Indonesian contexts, however, studies on how verbal and visual modes represent experiences and construct social position of the interactants seem to be underexplored. The present study examined three Indonesian picturebooks using the perspectives of multimodality and reported how the children's experiences were represented through the verbal and the visual modes used, and how these two semiotic resources represented the social relationship between the characters in the picturebook and the potential readers of the books. The examination of the verbal texts has been focused on the clauses as the building blocks of the texts by identifying the participants, process types, circumstances, and clause types. The examination of the pictures has been focused on such visual elements as who/what are in the picture, what activities taking place, the attributes possessed by the represented participants, and the circumstances. In addition, how the represented participants address the viewers was also examined. The results of the analysis show that ideationally the narrative is mostly centered around the activities done by and to children, which are presented as an offer to the readers. Verbally and visually the represented participants are socially equal to the children readers. The three picturebooks are excellent examples of picturebooks that present a narrative of Indonesian children designed for young readers because of their simple vocabulary, simply-constructed Indonesian grammar employed, and simple yet interesting plot they deal with.
\end{abstract}

Keyword: picturebooks; interactive meanings; verbal mode; visual mode

In a simple way picturebooks can be understood as books that are composed by two elements, narrative or the verbal text, and pictures or the visual text. Considering the different themes presented, picturebooks have been categorised into categories relevant with their potential or targetted readers. In relation with the presence of pictures on a text, picture books are not the only type of books using pictures to tell or show a story; illustrated books also make use of pictures in communicating the stories. The important difference between the two lies in the function of the pictures. The pictures in illustrated books serve the decorative or supportive function to the verbal that carries the main narrative. In picturebooks, however, both the verbal and the pictures are believed to be equally important for communicating the narrative (Nikolajeva \& Scott, 2000).
That pictures serve as the decorative or the supportive function to verbal text implies that the meanings are always dependent on the verbal text. Barthes (1967) argues that because pictures have so myriad of possible meanings, the verbal has to come to the rescue of 'fixing' or 'stabilising' their meanings. In the context of picturebooks, however, the narrative told by the verbal is interdependent with that shown by the pictures. To separate the two may make the narrative difficult to understand, if not impossible (Agosto, 1999).

Picturebooks are believed to be able to represent a place or a country and to portray how people who live there are (Cotton, 2008; Eppley, 2010). Eppley (2010) found that the pictures in the picturebooks she investigated depicted American rural people as the self-relying, closely connected, satisfied and joyful, diverse, expendable, and were described as 'other'. 
Meanwhile, American rural areas were depicted as expendable. Cotton (2008) found how Europe as a country with diverse culture is depicted by the illustrators of picturebooks for children in Europe. In the topic of picturebooks' illustration, Erekson (2009) found that when illustrators rely on conventional pictures, the readers miss their chance to make meaning of the story. Pictures in picturebooks were also found to influence children understanding of the story (Kaminsky, 2013). Picturebooks have also been considered to improve the development of children's literacy in their class (Torr, 2004; Tulk, 2005). Studies on picturebooks have also focused on how the verbal and the visual text as the bearer of meanings interact with each other to communicate their messages to the readers. These include for example Sipe (1998) who believed that the text synergizes with the pictures in creating the meaning of the narrative in picturebooks and the gap they leave is filled by their readers. Using Systemic Functional Linguistics (SFL) derived theories, researchers have directed their attention towards how different semiotics resources in picturebooks as a multimodal text construe experiences and world view (ideational meaning), how the producer of the picture books, the narrative and the represented participants in the picturebooks socially interact with the readers, despite being imaginary, and position their readers (interpersonal meaning), and how the two meanings are organised into a coherent whole of the text (compositional meanings) (for example, Guijarro \& Sanz, 2008; Painter, Martin, \& Unsworth, 2013, Young \& Serafini, 2013).

The rationale behind the use of SFL to probe into how experiences are construed in texts such as picturebooks, and how the social relation between the producer, the content of texts and their viewers are represented in the texts lies in the strength and the capability of SFL to provide the tool and the system of analysis. SFL as developed by Halliday (1994), Halliday and Matthiessen (2004) believes that language realizes three categories of meaning; it constructs our both physical and mental or logical experiences of the world, which is the ideational meaning of language. The lexico-grammatical system that is used to realize this metafunction is called transitivity which patterns our experiences into clauses. Its components are a process realized by verbs, participants which can be labelled as actor, senser, sayer, token etc., depending on the type of the process, and circumtances which are roughly similar to adverbs in transformational grammar. The language we exchange with our interlocutors positions us into a given social role either as the sender or receiver of the information, either demanding or giving information or a commodity. Hence, it enacts a social relation we have with them. This is the interpersonal meaning of language which is realised lexico-grammatically in what is called mood system. Its components are mood which consists of subject and finite, and residue, the rest part of the clause. The language we express orally or even more so in written form needs to be organized in such a way that it forms a coherent whole for the message to be well understood. This is the textual meaning of language. Textually the information we express is mapped into theme and rheme.

The recognition of "...many other modes of meaning, in any culture, which are outside the realm of language" (Halliday, 1978), and metafunctions theory (Halliday, 1994) have encouraged researchers to explore the use of and extend metafunction theory to other semiotic resources outside verbal language. This has been pioneered by O'Toole (1994) who applied them to make meaning of displayed arts, and Kress and Van Leeuwen (1996) who applied them into visual designs. Studies following these twopioneering works include among others works edited by O'Halloran (2004), volumes edited by Unsworth (2008), and works edited by Dreyfus, Hood, and Stenglin (2011). Kress and Van Leeuwen's application of Halliday's metafunctions theory has been the important base of their visual social semiotics theory. Despite some reservations against their SFL-based socio semiotic theory of reading the visuals (see for example Hagan, 2007; Forceville, 1999), Kress and Van Leeuwen have shown that metafunctions theory is a so powerful tool that we can use to look into and explain the meaning of such semiotic modes as pictures. In their theory of visual social semiotics, Kress and Van Leeuwen (1996) believed that pictures also convey these three strands of meanings. Pictures tell about something, they construe experiences about the world as perceived and offered by the maker. They convey ideational, or to use their term, representational meaning. A direct conversation enacts a social relation between those involved pictures, on the other hand, represent the social relation between the picture makers, what in the picture, and the viewer. This is the interpersonal, or interactive as Kress and Van Leeuwen (1996) call, of the pictures. Like verbal language that needs to be organized to form a coherent text, the elements of a picture according to them are composed into a picture as a whole integrated one. This is a textual or compositional meaning of pictures.

They further elaborated that transitivity system in pictures is realized through the use of vectors which serve like verbs in verbal language that realize actions. Vectors then give what are in a picture a role of either actor, reacter, sayer, or phenomenon. Analysing visual transitivity in pictures require the analysts to identify what or who are pictured, the 
represented participants, their activities, and the attributes attributed to them (Royce, 1999). Meanwhile, interpersonal relation between those involved in a communicative act is realized through three important devices in pictures, which are the absence or presence of gaze, the shot taken, and the type of angle used. The presence or absence of gaze directed between the represented participants and directed by them to the viewers involves all in a social relation, despite being imaginary. A gaze may realize a demand or offer that the viewers, or interactive participants can acknowledge or disclaim. Types of shot which are close, medium, and long realize a social proximity between the represented participants and the viewers, ranging from being intimate (close), socially close but not intimate (medium), and being stranger or foreign (long). The angle taken is another important feature of interactive meaning in visual designs. It construes power relation between viewers and what is viewed. A frontal vertical angle taken which positions the viewers above what is viewed gives them a higher social power over what is in the picture and vice versa, while a horizontal angle places the viewer and what is viewed in a relatively equal social position. The textual metafunction in visual design is realized through compositional layout elements such the position of the visual elements which construe information value, which visual elements get emphasized or made salient, and how the visual elements are framed (Kress \& Van Leeuwen 2006; Royce, 1999; Unsworth, 2008). Kress and Van Leeuwen's (1996) visual social semiotic theory has been employed in the present study to make meaning of the visual elements in the picturebooks investigated.

In the context of Indonesia, critical analysis on picturebooks have mostly been focused on how picturebooks serve as teaching media to help improve children's vocabulary mastery (in Indonesian, English or other languages), to teach (good) characters, and how different genders are represented in picture books. Studies on how children experiences are represented visually and verbally in picturebooks relying on SFL perspectives are very scarce.

Using SFL derived systems and tools of analysis along with Kress and Van Leeuwen's social semiotic theory to read visual designs, the paper reports how Indonesian children's experiences are both verbalized and visualized in picturebooks, and how the relation between these experiences and the children viewers is represented. In other words, what ideational or representational and interpersonal or interactive meanings can be unearthed from the picturebooks. The focus and the use of SFL theory in this paper may serve as an attempt to offer a new alternative in critically investigating picturebooks.

\section{METHOD}

For the purposes of the investigation three picturebooks Misteri di Pasar Terapung (A Mistery in the Floating Market) by Nukman and Elviana (2014), Lontong Cap Go Meh, by Dewayanti and Gina (2014), and Rumah untuk Ge (A Home for Ge) by Nukman and Dwijayanti (2014) have been selected to be investigated. All of the picturebooks are part of Bianglala Anak Nusantara (the Rainbow of the Archipelago's Children) series published by Litara Foundation, a non-profit organization dedicated to, among others, help improve the literacy of Indonesian children through the publications of picturebooks about Indonesian children. The picturebooks it publishes significantly differ from hundreds of picturebooks available in the bookstores in Indonesia which supposedly tell about Indonesian children in terms of their format, their content, and especially of their use of colors, and visual design in telling the narratives.

Two of the books investigated (Misteri di Pasar terapung, Lontong Cap Go Meh) present children as the main characters. Meanwhile in Rumah Untuk Ge, the main character is an animal, an elephant named Ge. Children in this picturebook serves as secondary characters that appear before the story comes into its end. However, the children did a very important thing to the main character which was saving it from people trying to hunt and torture it.

The analysis is two folds with verbal text of the picturebooks was analyzed using transitivity and mood system of systemic functional linguistics while the visual text was analyzed using visual social semiotics. The analysis was conducted on all pages of the books; 15 double spreads of Misteri di Pasar Terapung; 13 double spreads of Rumah untuk Ge; and 15 double spreads of Lontong Cap Go Meh. However, not all the images are able to be shown here; those shown are only the ones relevant to the points being discussed. The analysis was focused on two things; how the children's experiences were verbally and visually represented, the ideational meaning of the narrative, and how the picturebooks represented the relation between these experiences and the children readers, the communicative meaning of the narratives. As Indonesian is a language that does not recognize finite verbs as the concept of finiteness is realized differently from that of English, its discussion is not within the scope of the paper, mood analysis conducted on the verbal text to reveal the communicative meaning was aimed at identifying the type of clauses used and the role played by characters. In addition, the point of view or the narrative perspective used in telling the story was also identified. 


\section{FINDINGS}

The findings will begin with the results of transitivity and mood analysis of the verbal text, followed by the results of the analysis conducted on the visual text of the picturebooks. The transitivity analysis of verbal text in the picturebooks finds that Indonesian children's experiences as depicted in the picturebooks are mostly constructed and represented through the use of material processes (49); relational processes (34); mental processes (9); verbal processes (5), and existential processes (5). The following table summarizes this finding.

Table 1. Types of process found in the picturebooks.

\begin{tabular}{llrc}
\hline Title & Process & Number & Percentage \\
\hline Misteri di Pasar Terapung & Material & 29 & 56.8 \\
& Relational & 8 & 15.7 \\
& Mental & 8 & 15.7 \\
& Verbal & 3 & 5.9 \\
& Existential & 3 & 5.9 \\
\cline { 2 - 4 } & Total & 51 & $100 \%$ \\
\hline Lontong Cap Go Meh & Material & & 33.3 \\
& Relational & 12 & 52.8 \\
& Mental & 19 & 2.8 \\
& Verbal & 1 & 5.5 \\
& Existential & 2 & 5.5 \\
\cline { 2 - 4 } & Total & 2 & $100 \%$ \\
& & 36 & 69.2 \\
\hline Rumah Untuk Ge & Material & & 27 \\
& Relational & 18 & 3.8 \\
& Mental & 7 & $100 \%$ \\
& Verbal & - & \\
& Existential & 1 & \\
\cline { 2 - 4 } & Total & - & \\
& & 26 & \\
\hline
\end{tabular}

In two of the picturebooks (Misteri di Pasar Terapung, Rumah Untuk $\mathrm{Ge}$ ) the narrative is told by an external narrator who reports the feelings and what the characters are doing. In doing so the narrator used the characters' name more than the pronoun (dia $=$ he/she). The narrative in Lontong Cap Go Meh, on the other hand, is told through figural narrative situation (Klarer, 1999); the main characters (Lily and Nissa) tell and show how/what they are feeling and what they are doing. In Misteri di Pasar Terapung there are 51 clauses identified, forty nine of them are in the form of statements and only two are in the form of questions. The child character became the actor in ten clauses, the senser in five clauses, the sayer in one clause, and as a carrier in two clauses. Rumah Untuk Ge has 26 identified clauses, twenty-three of them are in the form of statements, three of them are in the form of questions. The main character was the actor in six clauses, and a carrier in five clauses. Lontong Cap Go $M e h$ has 36 identified clause complexes, all in the form of statements. The main characters become the actor in 8 clauses.

Having completed the analysis on the verbal text, the analysis was then conducted on the visual text of the picturebooks. Like the verbal transitivity analysis, visual transitivity analysis is aimed at identifying the participants, the process, and the circumtances. The following is the findings of the analysis.

In Misteri di Pasar Terapung, the human and animal represented participants identified are, Mawi, the child main character, mother, sellers, Pak Badu, and two Orang Utans. Mawi, the child character, plays a significant role throughout the story. In fact, the narrative basically revolves around him. All of the pictures are narrative processes, which according to Kress and Van Leeuwen (2006) "serve to present unfolding actions and events, processes of change, transitory spatial arrangements". The visual processes between the represented participants are mostly transactional reactional process; the vectors are made by the eyelines of the characters and as the characters exchanged look in many of the images, this creates a transactional process which is also birectional. There are also actional processes but they are mostly embedded.

In Lontong Cap Go Meh, the human represented participants identified are Nissa and Lily the children main characters, Nissa's father, Lily's mother, and neighbors. All of the pictures are narrative processes. The visual processes identified are mostly transactional reactional process involving especially the main characters, Nissa and Lily. In Rumah Untuk Ge, the main represented character is an elephant which is 
anthropomorphic. Humans attributes are attributed to the elephant so it can think, feel, and say like humans do. Two significant visual processes identified are actional processes in which Ge, the elephant became the goal, and transactional process in which Ge became the phenomenon. This is relevant with the narrative told in the picturebook which is about an elephant which escaped human torture, hunted by angry farmers, and finally being saved by concerned children who led it to Way Kambas, a specially designed reservation and training place for wild elephants in Lampung Indonesia.

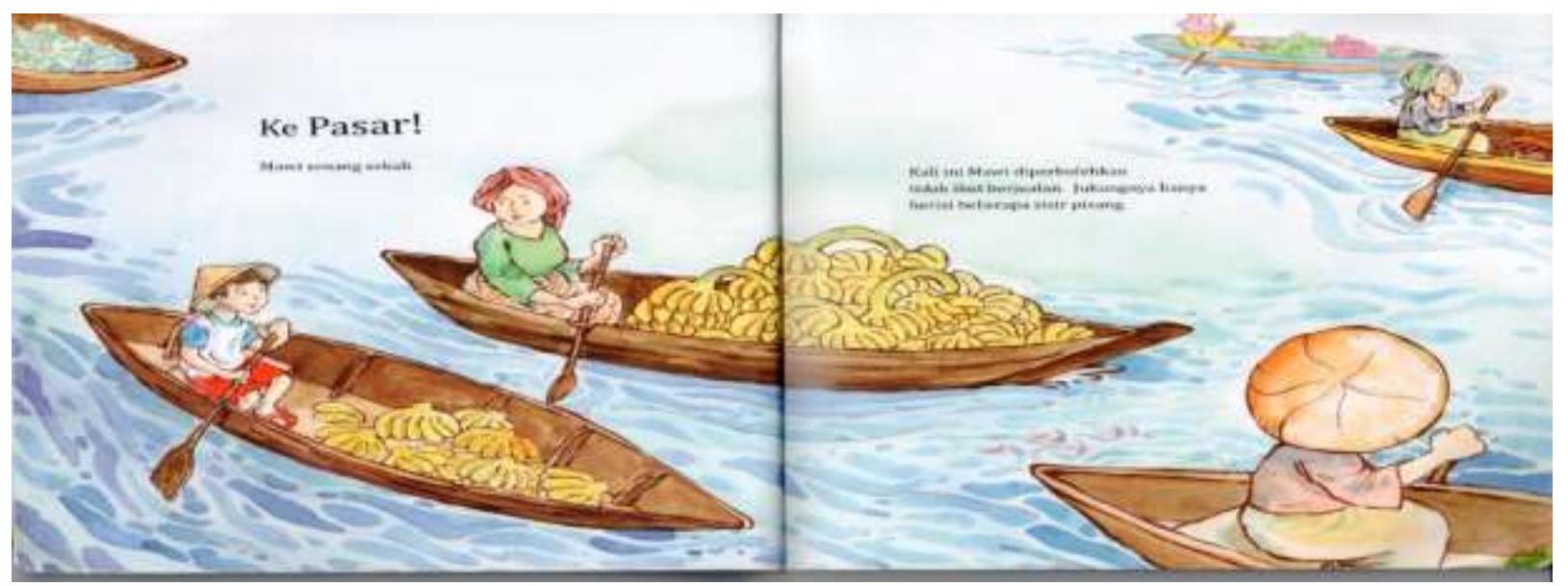

Figure 1. Transactional reactional image in Misteri di Pasar Terapung.

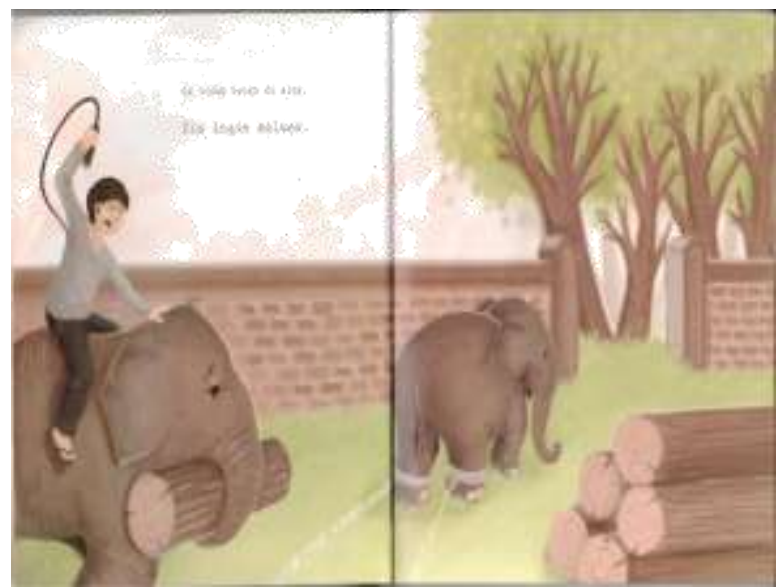

Figure 2. Transactional image with Ge, the main character as the phenomenon

The locative circumtances as the other participant in visual transitivity analysis identified in the picturebooks are different from one to another. In Misteri di Pasar Terapung, a big river is the main locative circumtance. Another locative circumtance is the Orang Utan Reservation where the story ends. In Rumah Untuk Ge, the main locative circumtances are a plantation and a reservation and training place for wild elephants, Way Kambas. In Lontong Cap Go Meh, the main locative circumtances identified are a house, main characters' neighborhood, and what seems to be the projection of the characters' mind.

The analysis on the interpersonal meanings, or to use Kress and Van Leewuen's term interactive meaning, of the picturebooks relies on the presence or

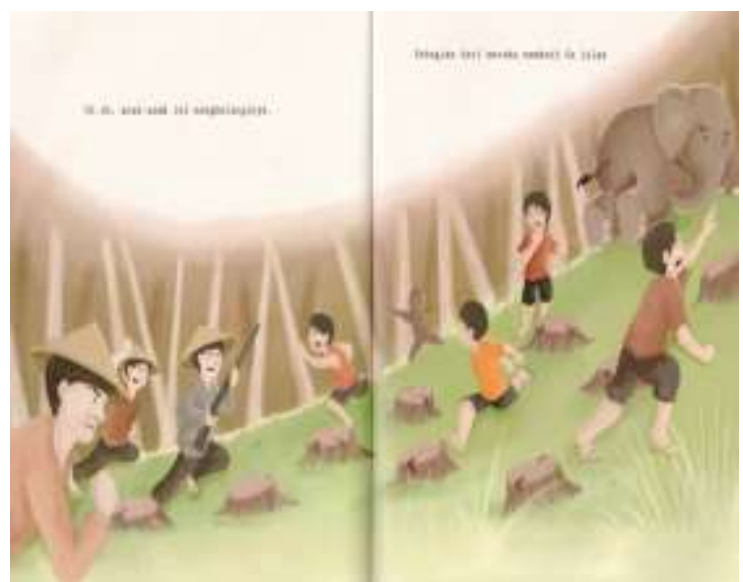

Figure 3. Actional image with $\mathrm{Ge}$, the main character as the goal.

absence of gaze of the represented characters, size of the frame, and the perspectives used in the images. The analysis finds that the gaze in almost all of the images in the three picturebooks creates an offer rather than a demand. The represented characters' gaze is not directed towards the readers but to either other represented participants or to other directions in the image. A demand is realized only by one spread image of Misteri di Pasar Terapung; the two Orang Utans in pak Badu's boat looked at Mawi, and the readers as he discovered them eating the banana they stole from a seller's boat.

The frame used in all the picturebooks is the edge of the page. Painter et al. (2013) call this type of frame unbound. This type of frame does not create any line 
boxing the images. In all three picturebooks most of the represented participants are pictured with a close shot, showing their full body, and sometimes an extreme

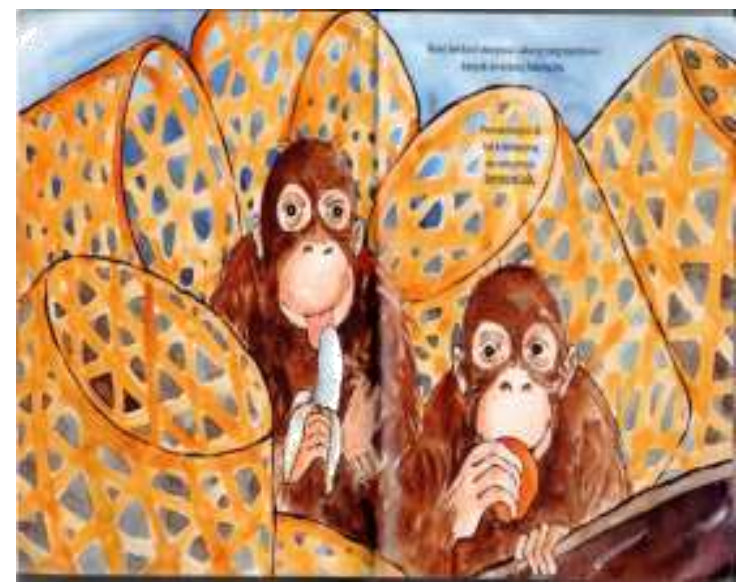

Figure 4. The gaze that creates a demand in Misteri di Pasar Terapung

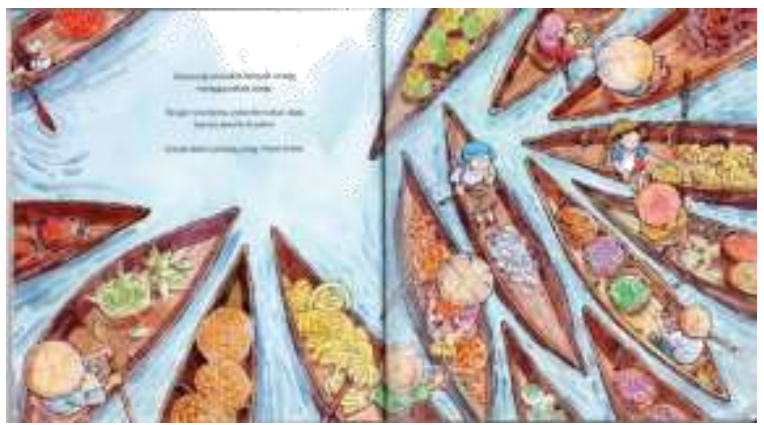

Figure 6. Vertical angle

\section{DISCUSSION}

The aim of this article is to investigate how Indonesian children's experiences of their wolrd are constructed and represented in picturebooks through the use of verbal text and pictures, and how these two modes represent relationship between these experiences with the children reading the picturebooks. Second, the paper aims at contributing to how picturebooks can be analysed multimodally using theories exptrapolated from SFL.

The transitivity analysis on the verbal text in the picturebooks has found that Indonesian children experiences are mostly represented through the use of material processes. These processes are especially significant in Misteri di Pasar Terapung and in Lontong Cap Go Meh. In Rumah Untuk Ge, relational processes dominated the experience of $\mathrm{Ge}$, the represented participant. These processes come second as the most frequently used process type. Material process is a process that indicates doing and happening (Halliday, 1994; Halliday \& Matthiessen, 2004), which refers to an entity doing or carrying out an action close up. The angle taken is mostly horizontal, presenting the represented participants from the front, mostly from eye level perspective.

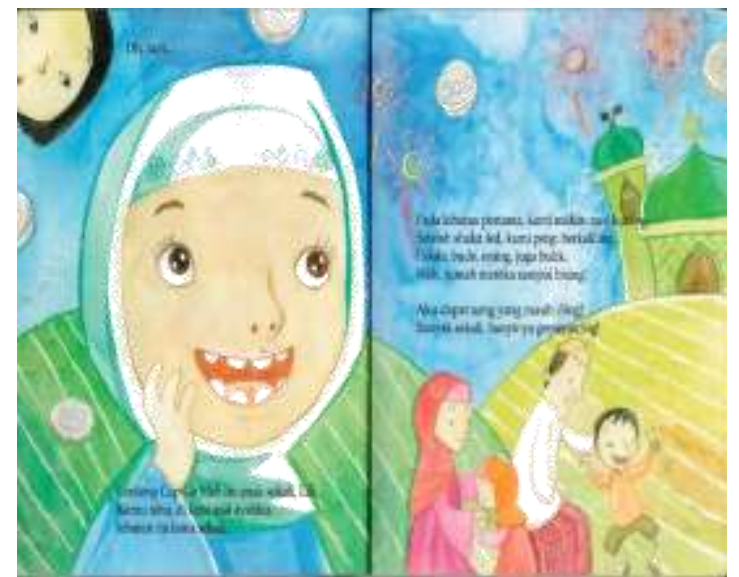

Figure 5. Extreme close up in Lontong Cap GoMeh.

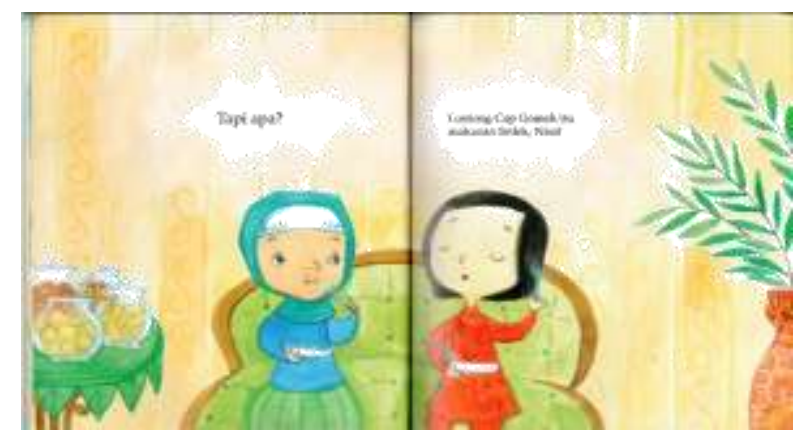

Figure 7. Eye level frontal angle

(Eggins, 2004, p. 215). The dominant use of material process gives a strong impression that children's experiences represented are mostly about the activities they do, often as their way of exploring their surrounding as in what Mawi, the main character of Misteri di Pasar Terapung did, shown in fig. 1. Translated into English the text reads (Ke pasar, Mawi senang sekali. Kali ini dia diizinkan untuk berjualan tidak bersama ibu. Perahunya penuh dengan pisang) "(Going) To the market, Mawi is thrilled. This time he is allowed not to trade along with his mother. His boat is loaded only with some bananas." He went to the floating market rowing his own boat, experiencing the hustle and bustle of people bartering goods as their way of doing business. The use of material processes in the picturebooks also allow the readers to feel the movement of the main characters and the development of the story. They, in the words of Guijarro and Sanz (2008), "contribute to the development of the plot by telling the child about the action carried out by the main characters". 
Relational processes, the second most frequently used process type, function to describe things by stating their primary qualities and for identifying (Halliday \& Matthiessen, 2004, p. 210). Relational processes do not have any meaning indicating actions, but they basically refer to states of being, conditions or qualities (Eggins, 2004, p. 237). The relational processes used in the picturebooks function to describe qualities or characteristics depicting the children main characters, objects, animals, and the locative participant where children characters carry out their activities. In addition, they are also used to describe the feeling of the main character. They allow the readers to possibly enjoy the same feeling, or to symphatize with the main characters. In Figure 2. the text which reads, "Ge tidak betah di sini. Dia ingin keluar" (Ge doesn't feel at home here. He wants to be out of the place), describes how Ge's feeling that the children readers can relate and feel sympathy for.

The verbal processes used in the picturebooks generate the roles of a sayer, verbiage (the thing being talked about), or target which receives what is being talked about. The use of these processes makes the represented children's world in the stories to contain a description of represented participants who tell a story, become something said, and become a recipient of what is said. The existential processes used simply indicate that something exists. Meanwhile, the mental processes used, a process type that is related to the world of human consciousness, give the main characters a role of a senser, the entity which thinks, identifies or feels and the role of phenomenon, the entity which is thought about, and identified. Clauses using mental processes make sense of the smallest change in the course of events taking place in the human consciousness (Halliday \& Matthiessen, 2004, p. 197), processes used to tell what individuals think about and feel (Eggins, 2004, p. 225). This means that in addition to involving physical activities, children experiences of their world also involve mental activities such as recognizing something or knowing for example a solution to a problem like what Mawi did when Pak Badu told him what they could do with the two Orang Utans, or what people usually do in a Lebaran feast like what Nissa in Lontong Cap Go Meh knew and informed Lily about.

The visual processes identified show that children's experiences represented in the picturebooks are mostly about interaction with other human beings, and with the nature, in this case, represented by an elephant. The children are the reacter/interacter. They actively involve with their surrounding and contribute to it in ways they are capable of. This representation is relevant with the mission of the publisher that is to empower the children by presenting stories about
Indonesian children who are active, smart, and contributing citizens.

In relation to the interactive meaning the texts are mostly presented in the form of statements. Halliday (1994) proposes four important speech functions in communication that can be summed up into two which are offering and demanding. An offer consists of offering information in the form of statement that can be agreed or contradicted; offering goods or service that can be accepted or rejected. Meanwhile a demand consists of demanding information in the form of questions that can be answered or disclaimed; demanding information or service in form of imperatives that can be done or rejected. The picturebooks present information about how Indonesian children live their life; what they do, and where they carry out the activities. These statements are worded in short sentences, sometimes with rhymes as in "Aku dapat uang yang masih cling! Banyak sekali, bunyinya gemerincing! (I got a lot of money that is still fresh! (It is so) much that it is jingling). It is unfortunate here that the English translation cannot retain the rhyme. The sentences used in the picturebook also have a conversational nuance, they don't use sophisticated vocabulary yet still employ good grammar. The address form used by the narrator in the sentences containing the main characters most of the times is their name. This creates the feeling that the main characters are people the readers know, the people they may bump into their real life, people the readers can have a conversation with. In brief, generally children experiences are presented as information offered to the readers, positioning them as observer of what the main characters do and feel.

The visual representation that presents the characters in their complete figure supports what is mentioned before. Further, the fact that in some images the main characters are pictured in an extreme close up suggests an intimacy between them and the readers. The readers are invited to enter into the mind of the main character and together with them live their mind projection as in Lontong Cap Go Meh, or to feel the panic that attacked the main character in Rumah Untuk $G e$ as if the readers were there. In most of the images (e.g., Figure $1 ; 3 ; 4 ; 7$ ) the angle taken is eye level, presenting the represented participants from the front. Throughout the story, indeed, there is a shift in perspective as in Misteri di Pasar Terapung, in which the angle of the images at the beginning of the story is vertical, positioning readers above the images (e.g., Figure 6) This allows the readers to have a bird eye view over the market. In Lontong Cap Go Meh, this perspective was used when Lily, one of the main characters, flew to the sky leaving Nissa on the ground as she explained what Cap Go Meh means from her Chinese tradition's outlook. This symbolizes that being 
knowledgeable about something may give you more power over those who are not. However, the images presented with this perspective are insignificant in number and so in general the readers are in an equal social position with the represented participants.

The double spread style, two pages combined together and the extending style of pictures from one end to another which is called "bleed" or in Painter et al.'s term (2013) "unbound", gives the sense that children's world in the picturebooks is borderless with that of the readers'. The readers are made to feel that what is pictured is their world; the action and activities done by and to the represented participants are the actions and activities that can also be done by and to them as readers. In brief, verbally and visually the represented participants are socially equal to the children readers.

\section{CONCLUSION}

The article has discussed the possible ideational and interactive meanings of three Indonesian picturebooks as an example of multimodal artefact. Transitivity and mood analysis have been employed to probe into the verbal text along with the analytical tools from reading images theory to unravel the representation in the images. Hence, the article has attempted to show, as many other scholarly articles, the application of SFL derived theories in making meanings of multimodal texts. Despite being simple, the article has shown that Halliday's language metafunction that has been extended in its application through the work of especially Kress and Van Leeuwen is able to dismantle how our experiences represented in such text as picturebooks, how they can be approached and elaborated thoroughly. This is relevant with Halliday's claim (1994) that one strength of SFL is that it is capable of elaborating texts better than other forms of grammar; part of the reason is the fact that SFL can specifically identify the different (social) role played by represented participants in the texts.

The three picturebooks are excellent examples of picturebooks that present a narrative of Indonesian children designed for young readers because of their simple vocabulary, simply-constructed Indonesian grammar employed, and simple yet interesting plot they deal with. In addition to these, the lively color used and the natural drawing of represented participants can really capture the young readers' attention as they go through every page of the picturebooks

\section{REFERENCES}

Agosto, D. E. (1999). One and inseparable: Interdependent storytelling in picture storybooks.
Children's Literature in Education, 30(4), 267280.

Barthes, R. (1967). Elements of semiology. 1964. New York: Hill \& Wang.

Cotton, P. (2008). Visualizing Europe through picture books: Where are we now? In J. A. Herding, What do you see? International perspectives on children book illustration (pp. 17-34). Newcastle: Cambridge Scholars Publishing.

Dewayanti, S., \& Gina, E. (2014). Lontong Cap Go Meh. Jakarta: Yayasan Litara.

Dreyfus, S., Hood, S., \& Stenglin, M. (2011). Semiotic margin: Meaning in multimodalities. London: Continuum.

Eggins, S. (2004). An introduction to systemic functional linguistics (2nd ed.). London: Continuum International Publishing Group.

Erekson, J. A. (2009). Putting Humpty Dumpty together again: When illustration shuts down interpretation. Journal of Visual Literacy, 28(2), 142-162.

Eppley, K. (2010). Picturing rural America: An analysis of the representation of contemporary rural America in picture books for children. Rural Educator, 32(1) 1-10.

Forceville, C. (1999). Educating the eyes? Kress and Van Leeuwen' reading images: The grammar of visual designs (1996). Language and Literature, 8(2), 163-178.

Guijarro, J. M., \& Sanz, M. J. P. (2008). Compositional, interpersonal and representational meanings in a children's narrrative: A multimodal discourse analysis. Journal of Pragmatics, 40, 1601-1619.

Hagan, S. M. (2007). Visual/verbal collaboration in print complementary differences, necessary ties, and an untapped rhetorical opportunity. Written Communication, 24(1), 49-83.

Halliday, M. A. K. (1978). Language as a social semiotics. London: Edward Arnold.

Halliday, M. A. K. (1994). An introduction to functional grammar (2nd ed.). New York: Routledge, Chapman and Hall, Inc.

Halliday, M. A. K., \& Matthiessen, C. M. I. M. (2004). Introduction to functional grammar. Oxon: Arnold.

Kaminsky, A. (2013). From reading understanding a story in the foreign language. CLELE Journal, 1(1), 19-38.

Klarer, M. (1999). An introduction to literary studies. London: Routledge.

Kress, G., \& Van Leeuwen, T. (1996). Reading images: The grammar of visual design. London: Routledge. 
Kress, G., \& Van Leeuwen, T. (2006). Reading images: The grammar of visual design (2nd ed.). London: Routledge.

Nikolajeva, M., \& Scott, C. (2000). The dynamics of picture books. Children's Literature in Education, 31(4), 225-239.

Nukman, E. Y., \& Elviana, E. (2014). Misteri di pasar terapung. Jakarta: Yayasan Litara.

Nukman, E. Y., \& Dwijayanti, H. (2014). Rumah untuk Ge. Jakarta: Yayasan Litara.

O'Toole, M. (1994). The language of displayed art. (2nd ed.). London: Routledge.

O'Halloran, K. (Ed.). (2004). Multimodal discourse analysis: systemic-functional perspectives. London/New York: Continuum.

Oksanen, U. (2008). Picturing the landscape of the knowledge society: A semiotic point of view on adolecents' pictorial metaphors. In L. Unsworth (Ed.), Multimodal semiotics (pp. 237-251). London/New York: Continuum.

Painter, C., Martin, J. R., \& Unsworth, L. (2013). Reading visual narratives: Images analysis of children's picture books. Bristol: Equinox Publishing Ltd.
Royce, T. (1999) Verbal-visual complementarity in the economist magazine (Unpublished Doctoral Dissertation). The University of Reading, Reading, England.

Sipe, R. L. (1998). How picture books work: A semiotically framed theory of text-picture relation. Children's Literature in Education, 29(2), 97-108.

Torr, J. (2004). Talking about picture books: The influence of maternal education on four-year-old children's talk with mothers and pre-school teachers. Journal of Early Childhood Literacy, 4(2), 181-210.

Tulk, S. (2005). Reading picture books is serious fun. English Teaching: Practice and Critique, 4(2), 89-95.

Unsworth, L. (Ed). (2008). Multimodal semiotics: Functional analyses in contexts of education. London/New York: Continuum.

Young, S., \& Serafini, F. (2013). Discussing picturebooks across perceptual, structural and ideological perspectives. Journal of Language and Literacy Education, 9(1) 185-200. 